\section{Lembaran Sejarah}

Volume 15 Number 1

April 2019
Page

3-12

\title{
Tinjauan Makna Kelberadaan Pura Hyang Api di Desa Kelusa, Bali
}

\author{
A.A. BAGUS WIRAWAN, FRANSISKA DEWI SETIOWATI SUNARYO, \\ A.A. AYU RAI WAHYUNI \\ Prodi Sejarah, Fakultas IImu Budaya, Universitas Udayana \\ Email Korespondensi: fransiska.d3w1@gmail.com
}

\begin{abstract}
This paper focuses on the structure and meaning of the existence of the Hyang Api Temple in Kelusa Village, Payangan District, Gianyar Regency, Bali Province. This temple is a place of worship (parahyangan) from Dewa Agni. From the structure, ritual form, and its function symbolizes the manifestation of Dewa Vishnu and Shiva. The problem raised in this paper is to find out how the structure of the Hyang Api Temple in Kelusa Village and what the meaning of ritual activities are carried out by Hindus in the Pura Hyang Api Village of Kelusa. Through this analysis it can show that there are indications of the existence of Kahyangan Tiga, Tri Murti. The Tri Murti concept in Bali can be seen in the form of a temple. The method used in this paper is the historical method, especially through the collection of historical facts, namely the collection of written data in the form of documents and monuments. Through this analysis, it is expected that the public can have a better understanding of the form and meaning of temples in Balinese society.
\end{abstract}

\begin{abstract}
Abstrak
Makalah ini memfokuskan pada struktur dan makna keberadaan Pura Hyang Api di Desa Kelusa, Kecamatan Payangan, Kabupaten Gianyar, Provinsi Bali. Pura ini adalah tempat ibadah (parahyangan) dari Dewa Agni. Dari struktur, bentuk ritual, dan fungsinya melambangkan manifestasi Dewa Wisnu dan Siwa. Permasalahan yang diangkat dalam makalah ini adalah untuk mengetahui bagaimana struktur Pura Hyang Api di Desa Kelusa dan apa makna dari aktivitas ritual yang dilakukan oleh umat Hindu di Pura Hyang Api Desa Kelusa.Melalui analisis ini dapat menunjukkan bahwa ada indikasi keberadaan Kahyangan Tiga, yang disebut Tri Murti. Konsep Tri Murti di Bali dapat dilihat dalam bentuk pura. Metode yang digunakan dalam makalah ini adalah metode historis, terutama melalui pengumpulan fakta sejarah yaitu pengumpulan data tertulis dalam bentuk dokumen dan monumen. Melalui analisis ini, diharapkan masyarakat dapat memiliki pemahaman yang lebih baik tentang bentuk dan makna pura dalam masyarakat Bali.
\end{abstract}

Keywords: function; Pura Hyang Api; structure; symbolic meaning

Kata Kunci: fungsi; makna simbolis; Pura Hyang Api; struktur 


\section{Pengantar}

Bali dikenal dengan julukan Pulau Seribu Pura, karena realitasnya terjadi demikian. Hampir setiap rumah tangga orang Bali memiliki tempat sembahyang (pura, merajan, sanggah, paibon, dadya swagina. Demikian pula setiap banjar, desa, subak, perkantoran mempunyai puranya masing-masing. Pura-pura itu sangat fungsional, terpelihara, terawat dan tetap hidup sebagai bagian penting dalam kehidupan masyarakat Hindu di Bali.

Salah satu pura di Bali yang menarik untuk dibahas adalah Pura Hyang Api di Desa Kelusa. Pura Hyang Api merupakan salah satu pura kuno di Bali yang diperkirakan telah ada sejak abad ke-8 Masehi. Pura ini bertempat di Desa Kelusa Kecamatan Payangan Kabupaten Gianyar, Pura ini digolongkan sebagai Pura Kahyangan Jagat seperti halnya Pura Besakih di Kabupaten Karangasem.

Selain itu disebutkan pula bahwa pura ini mempunyai kaitan dengan perjalanan Rsi Markandhya dalam mengembangkan konsep ajaran Agama Siwa (Tripaksashakti) di Bali. Pura Hyang Api berlokasi di kawasan Munduk Gunung Lebah yang merupakan rute perjalanan suci dharmayatra dan tirtayatra maharsi tersebut yang diikuti oleh pengikut-pengikutnya yaitu Wong Aga. Dikawasan itu terdapat juga dua pura selain Pura Hyang Api yang memiliki hubungan dalam perjalanan rsi tersebut yaitu Pura Luhuring Akasa sebagai sthana Dewa Siwa dan Pura Gunung Gempal sebagai sthana Dewa Wisnu kedua pura ini berlokasi di Desa Adat Yeh Tengah.

Pura Hyang Api adalah pura yang digunakan sebagai tempat memuja Ida Sang Hyang Widhi Wasa atau Tuhan Yang Maha Esa dalam wujud Dewa Brahma. Keunikan dari Pura Hyang Api di Desa Kelusa ini diyakini digunakan oleh para umat (pemedek) untuk memohon kewarasan, kelanusan wewalungan (hewan ternak) bagi umat Hindu dari seluruh Kabupaten/Kota di Bali. Keunikan lainnya adalah di pura ini rutin diadakan persembahan Aci Keburan dengan mengadu atau melagakan ayam jantan untuk mempersembahkan punagi atau nazar karena kesembuhan dan keberhasilan ternaknya.

Dari gambaran latar belakang dapat dirumuskan masalah dalam tulisan ini yaitu : Bagaimana struktur Pura Hyang Api di Desa Kelusa dan apa makna yang

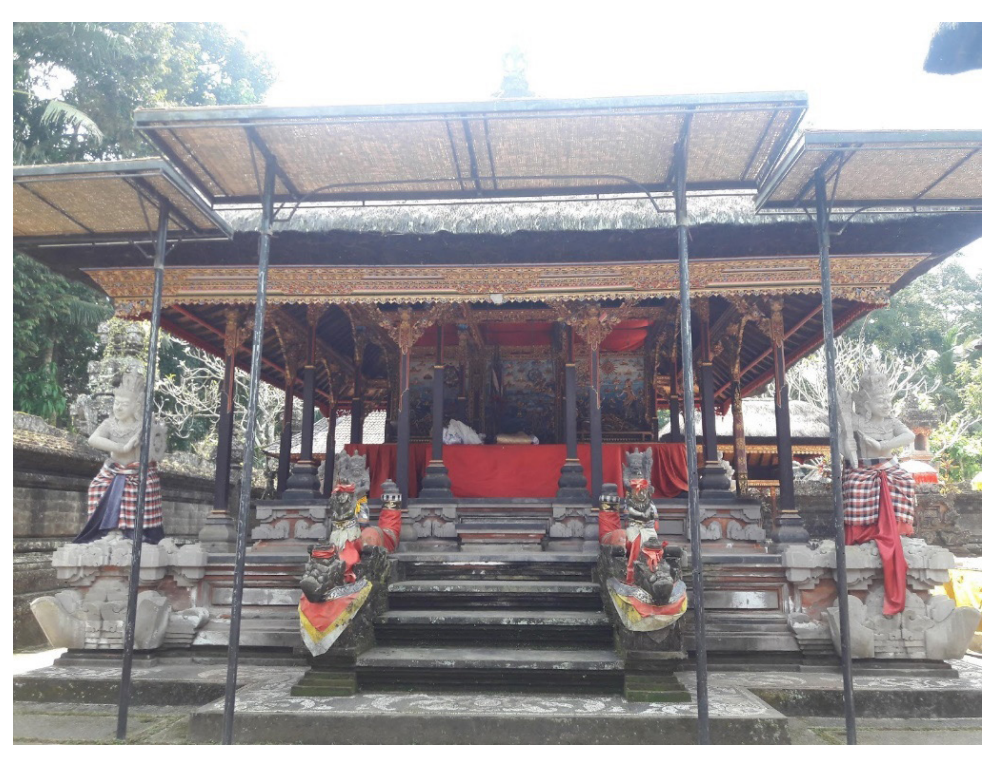

Figur 1. Paruman Agung Pura Hyang Api Desa Kelusa. Dok. Milik Penulis 
dapat ditangkap dari aktivitas ritual yang dipraktekkan oleh masyarakat pemujanya?

Makalah ini mengangkat tema sejarah di pedesaan. Pendekatan yang digunakan ialah sejarah mikro yang menekankan pada aspek prosesual atau diakronis dan aspek strukturalnya. Sumber data diperoleh dari sumber tertulis dan dari sumber lisan dari para informan, oleh karena itu metode menekankan pada metode kualitatif dengan melengkapi pedoman wawancara.

\section{Pembahasan}

\section{Struktur Pura Hyang Api}

Pura Hyang Api Desa Kelusa mengunakan konsep Tri Mandala dalam strukturnya. Tri Mandala diartikan sebagai konsep tiga wilayah atau daerah sebagai simbolisasi tiga alam atau Tri Bhuana (Bhur,Bhuwah, Swah)yang dipercayai oleh umat Hindu. Berdasarkan tulisan Nengah Subadra dikatakan bahwa dalam pura konsep ini dapat dianggap sebagai penentu dari batas-batas kesucian suatu pura. Maka dalam membahas suatu pura pengunaan konsep ini banyak memiliki pengaruh. Adapun bagian konsep ini terbagi atas tiga yaitu: 1. Nista Mandala, 2. Madya Mandala, dan 3. Utama Mandala.

Nista Mandala merupakan zona terluar dari pura dalam konsep Tri Mandala. Berdasarkan kepercayaan Hindu, bagian ini dianggap sebagai lambang Bhur Loka. Pada Zona ini, Pura Hyang Api kelilingi oleh dinding yang terbuat dari batu bata merah dan sedikit ornamen batu padas yang didalamnya terdiri atas satu Candi Bentar, dua Candi Peletasan, Wantilan, Ruangan Kantor, Tempat Pemujaan Aci Keburan,Sedan Penyawungan, dan juga areal Toilet (WC).

Madya Mandala merupakan zona ini terletak di tengah bangunan atau pura dalam konsep Tri Mandala. Zona ini merupakan lambang dari Bhuwah Loka. Pada zona ini sama dengan zona terluar dikelilingi oleh dinding yang terbuat dari batu padas dan bata merah tapi bangunan yang ada adalah dua Candi Bentar, Bale Kulkul, Bale Gong, Bale Pesandekan, Perantenan, Panggungan, Bale Angklung, dan Apit Lawang.

Utama Mandala/Jeroan merupakan tempat terdalam dan tersuci dari pura dalam konsep Tri Mandala. Zona ini merupakan lambang dari Swah Loka. Biasanya ketika akan memasuki zona ini digunakan Candi Kurung yang berisikan tiga pintu, tetapi pada Jeroan Pura Hyang Api pintu yang digunakan adalah dua Candi Bentar. Dinding yang digunakan untuk membatasi zona ini, juga masih merupakan susunan padas murni yang diinangi oleh lumut-lumut dan belum diperbarui seperti pada dua zona sebelumnya. Selain itu pada zona ini terdapat Aling-Aling, Bale Patok, Bale Paselang, Pawedan, Bale Pepelik, Pengideban Artabrana, Pekoleman, Tempat Tirta, Pelinggih Jro Sedan Ngurah Agung, Gedong Sineb, Padmasana, Meru, Taksu, Sedan Penganter, Panggungan, Lumbung, Bale Pesandekan Mangku, dan Paruman Agung. 


\section{Makna Pemberi Berkah Dalam Budaya Petani Pedesaan}

Sistem religi adalah bentuk keyakinan yang paling tua dari budaya petani. Dalam kesehariannya kehidupan petani di pedesaan di Bali ditandai dengan bersahabat dengan alam lingkungannya. Mereka bekerja senantiasa memohon kepada Dewa-dewa pujaannya agar produksi dan panennya terbebas dari serangan hama. Selain punya bangunan suci di area sawahnya untuk memuja Dewi Padi (Dewi Sri) dan Dewi Air (Ulun Siwi), mereka juga menyiapkan persembahan suci (yadnya) di Pura Hyang Api. Meskipun Pura Hyang Api di manifestasikan Dewa Agni (Brahma) namun dalam praktek ritualnya dikaitkan dengan mohon berkah kesuburan segala binatang ternak, peliharaan( satwa sato, satwa wawalungan, satwa paksi, satwa wina, dll) penopang aktivitas masyarakat agraris. Praketk religi ritual seperti disebutkan ditandai dengan ritual persembahan setiap 210 hari sekali jatuh pada Hari Sabtu Kliwon, yang oleh umat Hindu di Bali disebut hari kelahiran hewan ternak peliharaan (weton, wedalan), yaitu Tumpek Kandang. Persembahan kepada mahapencipta ternak peliharaan (Sanghyang rare angon) yang diperingati setiap hari Sabtu Kliwon (Tumpek Kandang) menurut masyarakat di Desa Kelusa, dikaitkan dengan pemujaan Dewa Agni di Pura Hyang Api (Ngurah Oka Supartha, 1996: 113). Keyakinan Masyarakat ini didasarkan atas Dewa Agni adalah sumber energi alam semesta (Bhuwana Agung) dan alam manusia (Bhuwana Alit). Dewa Agni juga sumber kemakmuran dan pemberi berkah berkembang biaknya binatang ternak peliharaan umat manusia (wawancara dengan Gusti Ngurah Jelantik, Juli 2018). Keyakinan masyarakat dikuatkan dengan pemujaan kepada simbol-simbol suci berupa wujud hewan yang disucikan (Tapakan)Barong Bangkal dan Barong macan.

Keyakinan pemberi berkah budaya petani yang ditandai dengan permohonan kesuburan di sawah dan ternak peliharaan merambah hingga kemasyarakat Hindu di Bali. Mereka yakin terhadap berkah yang didapat terutama bagi usaha-usaha peternakan di masing-masing rumah tangga. Keberhasilan kemakmuran yang diperoleh disertai persembahan kaul berupa mempersembahkan ayam aduan pada ritual Aci Keburan yang jatuh pada hari Sabtu Kliwon Kuningan, yaitu tepat pada Hari Raya Galungan-Kuningan. Ritual ini dipraktekkan setiap 5 hari berikutnya yaitu setiap kliwon selama 42 hari. Dimulai Hari Sabtu Kliwon Kuningan berakhir pada hari Sabtu Kliwon Klurut (Tumpek Klurut). Ritual Aci Keburan inilah dapat dimaknai sebagai ritual unik yang hanya dipraktekkan di Pura Hyang Api (Ngurah Oka Supartha,1996:110-111). Ritual ini terkait dengan fungsi Pura Hyang Api sebagai stana Dewa Agni yang berfungsi memohon berkah kesuburan produksi ternak peliharaan umat Hindu di Bali. Ketika Aci Keburan digelar maka umat Hindu di Bali dari yang berprofesi Peternak termasuk juga orang-orang yang diberkahi kewarasan yaitu kesehatan lahir batin ikut mempersembahkan (ngaturang) persembahan berupa ayam yang di adu 
ditempat yang sudah tersedia yaitu di areal jaba tengah dari struktur fisik tri mandala pura (wawancara dengan I Nyoman Suarka, 5 Juli 2018)

\section{Makna Pemersatu Umat Hindu di Bali}

Dilihat dari struktur fisik, bentuk ritual dan fungsi dari bangunan suci (pelinggih) dan bentuk-bentuk media pemujaan, maka terlihat jelas bahwa Pura Hyang Api di Desa Kelusa dapat dikatagorikan pura umum (Khayangan Jagat) yaitu pemujaan Sang Hyang Widhi dengan prabhawaNya dalam Brahma, Wisnu dan Siwa, Tri Murti (Komang Budaarsa,dkk, 2012: 3-4).

Media pemujaan yang ada ialah Keris, Arca Rambut Sedana, Arca Lingga Yoni, Terompong dan Ratu Gede berupa Rangda, Barong Bangkal dan BarongMacan (Wawancara dengan Jero Mangku Gusti Ngurah Jelantik, Juli 2018). Atas dasar kelengkapan media yang disucikan (pratima, arca) dapat dikatakan bahwa status Pura Hyang Api digolongkan berstatus kahyangan jagat atau tempat pemujaan umum umat Hindu dan bukan pemujaan leluhur dari catur warga atau catur wangsa.

Pada hari-hari ritual besar di Pura Hyang Api yaitu ritual peringatan 210 hari sekali pada hari Sabtu Kliwon (Tumpek Uye) dan pada hari sabtu Kliwon Kuningan (Kuningan) umat Hindi dari seluruh Bali datang membawa sesajen (banten) untuk memuja Tuhan Yang Maha Esa( Sanghyang Widhi Wasa) dalam wujud Brahma, Wisnu, Iswara, Rare Angon. Mereka memuja Tuhannya untuk memohon keselamatan, kemakmuran dan kesejahteraan alam semesta (Bhuwana Agung) dan sehat lahir batin bagi dirinya masing-

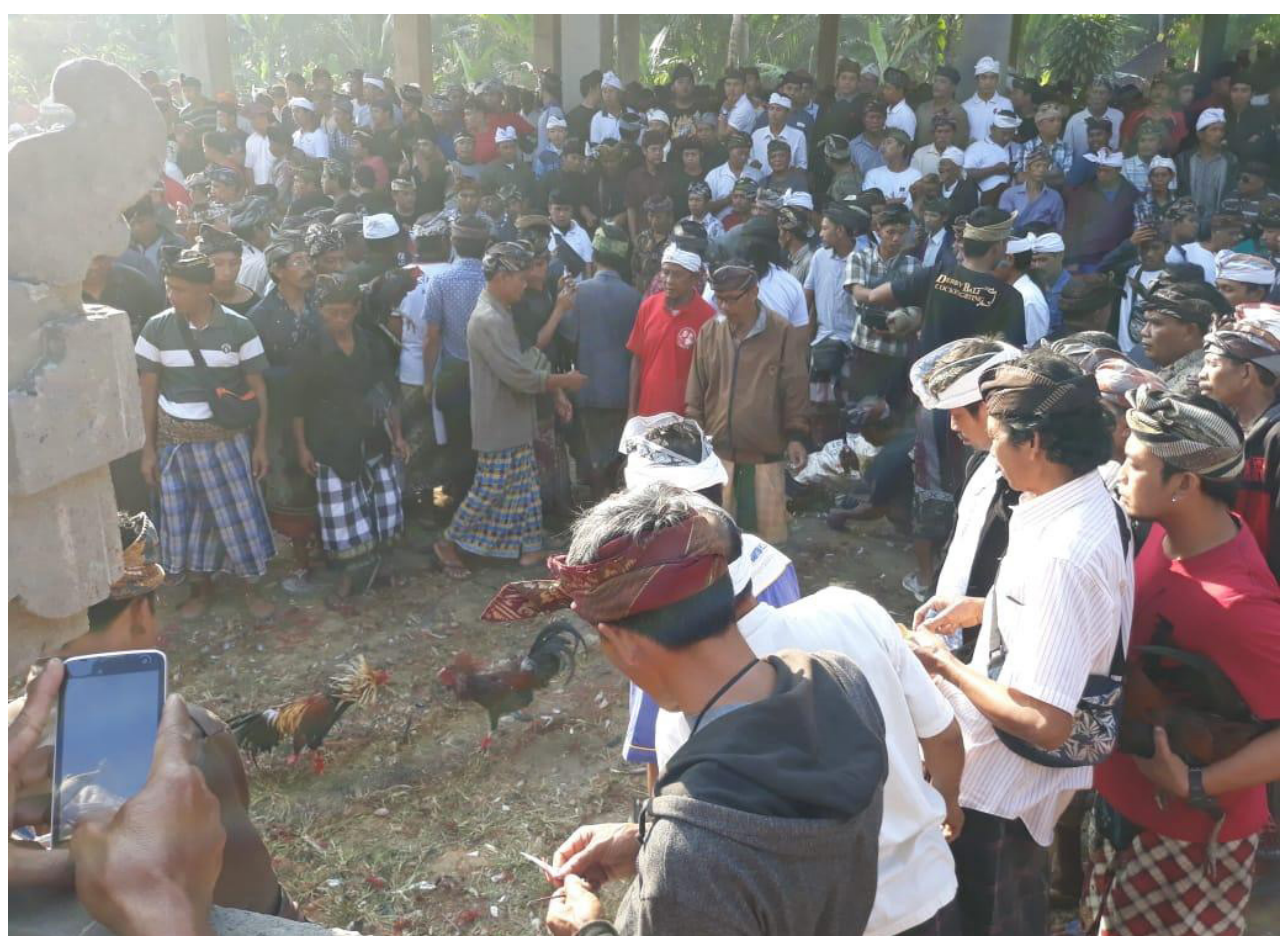

Figur 2. Ritual Aci Keburan di halaman Wantilan Pura Hyang Api Desa Keluasa. Dok. Milik Penulis. 
masing(Bhuwana Alit). Mereka memohon keselamatan melalui media percikan air suci (tirta, wangsuhan banyu cokor). Bhatara Bhatari yang berstana di bangunan-bangunan suci (pelinggih-pelinggih yang ada di Pura Hyang Api.

Kehidupan religius umat Hindu di Bali dapat dilihat praktek keimanan dan ketaqwaan yang saling terjalin bersatu antara manusia dengan Maha Pencipta, hubungan integratif perasudaraan sesama umat Hindu dan hubungan yang dipraktekkan dalam ritual yang disebut Aci Keburan. (Wawancara dengan Bendesa Adat, Juli 2018).

Pemersatu umat Hindu sangat kental ketika ritual-ritual besar dilaksanakan di Pura Hyang Api. Menurut panutan Jero Mangku Pura yang menyatakan bahwa "umat dari pelosok seluruh Bali datang memuja (Pedek Tangkil), memohon keselamatan lahir batin melalui sembahyang disertai media sesajen (banten) kemudian memohon air suci (tirta) baik untuk yang datang maupun dibawa pulang untuk keluarganya di rumah." (wawancara dengan Jero Mangku Gusti Ngurah Jelantik, Juli 2018).

Umat Hindu dari seluruh Bali yakin akan berkah religius magis dari Tuhan dan manifestasinya (Bhatara-Bhatari) yang berstanda di Pura Hyang Api, jelas dari pernyataan Jero Mangku dapat ditangkap makna bahwa Pura Hyang Api menjadi wahana mempersatukan umat Hindu tanpa membedabedakan kelahirannya (wangsa, warga, treh).

\section{Makna Pendidikan}

Bentuk praktek-praktek ritual religius dengan fungsinya masing-masing di Pura Hyang Api merupakan implementasi nilai-nilai yang perlu diaktualisasikan dalam kehidupan sehari-hari. Nilai-nilai tersebut contohnya adalah nilia pendidikan bagi umat Hindu. Pemahaman sistem yang saling berhubungan dengan konsep trihitakarana adalah pondasi sikap prilaku yang mengedepankan satunya pikiran kata dan perbuatan. Tiga unsur yang senantiasa melekat dalam jasmani dan ragawi manusia Hindu di Bali ini lebih dikenal dengan trikayaparisudha. Konsep-konsep ini senantiasa dijadikan pedoman dalam pendidikan menurut Hindu di masyarakat pemujaannya di Pura Hyang Api yang menggema ke seluruh umat Hindu yang pernah datang untyk memuja pada saat-saat ritual besar.

Praktek ritual religious pada hari-hari wedalan dan petoyan serta Aci Keburan dapat dimaknai sarat aspek pendidikan terutama nilai-nilai pendidikan karakter dan oral umat manusia pada umumnya. Makna praktek ritual yang dilaksanakan secara terus menerus sesungguhnya aktual dalam menanamkan nilai-nilai moral kebajikan.

Praktek ritual Aci Keburan di Pura Hyang Api yang dimulai bertepatan dengan Hari Raya Kuningan selama satu bulan lebih (42 hari) berakhir pada hari Sabtu Kliwon Krukut (Tumpek Krukut) adalah praktek pendidikan tentang nilai kejujuran, adil, permainan yang menjunjung tinggi nilai-nilai keadilan dan keterbukaan. Aci keburan membuka arena permainan adu ayam 
(tajen), tanpa disertakan taruhan (metoh). Aturan permainannya tidak sama dengan peraturan tajen atau tabuh rah.

Ketika adu ayam dalam Aci Keburan di gelar bisa mencapai 200 pasang aduan selama kurang lebih 5 sampai 6 jam, dari pagi berakhir pukul 10.00 (Wawancara dengan I Nyoman Suarka pada 6 Juli 2018). Arena penyelenggaraannya menempati madya mandala di Jaba Tengah dari struktur fisik Pura Hyang Api.

Praktik ritual Aci Keburan bermula pada Hari Raya Kuningan. Selanjutnya diselenggarakan secara terus menerus setiap lima hari sekali pada setiap hari Kliwon selama delapan kali, sebulan lebih (42 hari) sampai berakhir pada hari Sabtu Kliwon Krukut (Tumpek Krukut). Praktek Aci Keburan ialah persembahan dan pemujaan untuk membayar kaul (naur, punagi, sesaudan, sesangi) di Pura Hyang Api (Ngurah Oka Supartha ,1996:127). Ritual Aci keburan bermakna satunya kata dengan perbuatan yaitu menepati janji sangat aktual dijadikan nilai-nilai pendidikan di masyarakat. Para pelaku yaitu pemilik ayam yang di adu adalah umat suami istri yang datang memuja (pemedek) mempersembahkan persembahan kaul kepada Tuhan Yang Maha Esa dalam wujud Dewa Agni, Brahma di Pura Hyang Api. Mereka yang laki-laki (para suami) membawa dua ekor ayam atau lebih untuk di adu tanpa ada taruham (toh). Apabila ayam sudah usai diadu di akhiri dengan persembahyangan di depan bangunan suci (Pelinggih) Apit Surang disertai persembahan upakara (banten). Uniknya ialah, para pria (suami) mempersembahkan Aci Keburan dan para wanita (istri) mempersembahkan upakara (banten suwinih) disertai hewan- hewan peliharaan yang sudah dimasak (Ngurah Oka Supartha,1996: $128,131)$.

\section{Makna Kearifan Lokal tentang Pelestarian Ekosistem}

Aturan praktek ritual di Pura Hyang Api dan praktek kehidupan sehari- hari di masyarakat masih di temukan kesenjangan. Pelestarian ekosistem yang diyakini oleh umat Hindu di bali tercermin pada tradisi yang diwariskan dalam konsep Trihita Karana. Pada tahun 1980an konsep Tri Hita Karana di perkenalkan oleh I Gusti Ketut kaler dalam bukunya yang berjudul Butir- Butir Tercecer Tentang Adat Bali ( Kaler, 1983: 85-89). Konsep Tri Hita Karana mengajarkan hidup dan kehidupan yang harmonis lestari antar manusia dan lingkungannya atau ekosistemnya.

Umat Hindu yang datang memuja pada praktek ritual di Pura Hyang Api adalah praktek persembahan kepada kehidupan fauna dan flora. Ritualritual uatama yang dipraktekkan di Pura Hyang Api jatuh pada hari-hari kelahiran alam, hewan ternak, binatang, tumbuh-tumbuhan yaitu pada hari Sabtu Kliwon (Tumpek). Oleh karena itu di antara hari tumpek hanya Tumpek Wayang yaitu hari lahirnya wayang pada Sabtu Kliwon Wuku Wayang saja tidak dirayakan di Pura Hyang Api. Hari-hari tumpek lainnya 
senantiasa menjadi hari -hari yang mendapat pemujaan di sertai upakaranya (bebanten). Tumpek persembahan kepada hewan ternak, binatang peliharaan sehingga disebut juga Tumpek Kandang. Tumpek Landep persembahan kepada segala yang tajam atau barong yang terbuat dari logam. Tumpek Wariga atau Tumpek Uduh/ pengantar persembahan kepada pepohonan dan tumbuh-tumbuhan.

Praktek ritual yang unik ialah persembahan yang khusus ditujukan kepada dewa penguasa hewan ternak peliharaan yaitu Aci Keburan. Ritual ini disertai atraksi persembahan berupa adu ayam jago oleh umat Hindu yang pernah berkaul untuk keberhasilan usaha mereka. Ritual Aci Keburan di mulai pada hari Tumpek Kiningan, dilajutkan pada lima hari sekali pada setiap hari Kliwon berturut-turut hingga berakhir pada hari Tumpek Krukut (Wawancara dengan Jero Bendesa pada Juli 2018, Ngurah Oka Supartha,1996:128-129). Dari praktek ritual di Pura Hyang Api dapat dimaknai sebagai kearifan lokal tentang pelestarian ekosistem meskipun pada praktek kehidupan sehari-hari tidak sepenuhnya bisa dilaksanakan oleh warga masyarakat. Kehadiran barang-barang dengan kemasan plastik misalnya telah merambah hingga ke desa-desa sangat sulit hindari. Padahal di desa-desa belum ada dan sanggup untuk mendaur ulang limbah yang berasal dari plastik. Meskipun demikian kesadaran warga akan pentingnya menanam pohonpohon disekitar desa masih nampak. Terutama pohon-pohon yang kayunya bernilai ekonomis yaitu penyediaan bahan baku untuk pengadaan produk seni kerajinan berupa patung dan bahan bangunan (Wawancara dengan Made Parwata,10 Juli 2018).

Rasio lahan pemukiman penduduk dan lahan pepohonan memperlihatkan keasrian dan kelestariannya. Lokasi Pura Hyang Api masih dikelilingi dengan pepohonan seperti hutan desa. Ditambah lokasi desa yang berada di ketinggian perbukitan memberi cuaca kesejukan. Oleh karena itu pelestarian ekosistem yang masih bisa dipertahankan dapat dimaknai menjadi aset desa dan kearifan lokal.

\section{Makna Pengobatan dan Penyembuhan Penyakit Lahir Batin}

Menurut penuturan Jero mangku Gusti Ngurah Jelantik,ia sering diminta oleh warga umat Hindu dari luar desa untuk dimohonkan berkah penyembuhan sakit lumpuh. Jero Mangku memohon air suci (tirta wangsuh penawar) dari benda yang disucikan (pratina) berupa Barong Bangkal dan Barong Macan yang distanakan di sebuah bangunan (Pelinggih Pekoleman). Berkat air suci (tirta wangsuh penawar) yang diperciki dan diminum oleh pasien dari Padang Sambian Denpasar lama kelamaan sakit lumpuhnya sembuh (Wawancara dengan I Gusti Ngurah Jelantik,5 Juli 2018).Kesembuhan itu oleh keluarga pasien diikuti oleh kaul berupa ayam aduan yang dipersembahkan (penauran) pada ritual Aci Keburan. 
Dari praktek-praktek penyembuhan, berkah kesuburan, berkah kesehatan hewan -hewan peliharaan maka dapat dikatakan Pura Hyang Api pemberi berkah kepada keselamatan kehidupan manusia dan ekosistemnya berupa hewan binatang dan tumbuh-tumbuhan. Hal ini tercermin pada praktek ritualnya pada hari-hari Tumpek. Dari enam kali tumpek pada peredaran wariga menurut kalender Bali, hanya Tumpek Wayang saja yang tidak dirayakan di Pura Hyang Api. Praktek ritual yang senantiasa jatuh pada hari Tumpek dapat dikaitkan dengan simbol dewa-dewa yang dipuja dengan media tertentu. Ada media berupa benda-benda yang disucikan (arca, pratima) yang distanakan di bangunan-bangunan suci (pelinggih-pelinggih) yang ada di dalam pura. Arca berupa Rambut Sedana distanakan di bangunan Pelinggih Meru Tumpang Satu, Keris Pusaka distanakan di pelinggih Meru Tumpang Tiga. Arca Lingga Yoni di stanakan di Pelinggih Gedong Sineb. Alat gamelan sebuah terompong dan Ratu Gede, Rangda, Barong Bangkal dan Barong Macan distanakan di Pelinggih Pakoleman.

Pelbagai makna yang teridentifikasi memberi ciri unik keberadaan Pura Hyang Api di Desa Kelusa yang tidak dimiliki oleh Pura-Pura Hyang Api yang ada di Desa Kelusa lainnya di Bali. Struktur pura dengan pembagian tiga ruang (Trimandala) menunjukkan persamaan dengan Pura Hyang Api lainnya. Namun jika di analisis bentuk-bentuk ritual, benda-benda suci, dan fungsi-fungsinya maka aspek yang menunjukkan perbedaan dan keunikannya.

\section{Simpulan}

Pura Hyang Api di Desa Kelusa Kecamatan Payangan Kabupaten Gianyar menunjukkan ciri-ciri unik jika ditinjau dari aspek bentuk-bentuk ritual struktur, fungsi dan makna tidak terbatas pada tempat ibadah umat Hindu di Bali tetapi juga bisa dimaknai dari aspek-aspek pemberi berkah kesuburan tanaman para petani, makna pemersatu umat Hindu, makna pendidikan, makna kearifan lokal dan makna penyembuhan lahir dan batin.

Dari struktur Pura Hyang Api dapat dilihat bahwa pura ini dibangun mengynakan konsep tiga ruang (Trimandala), untuk memuja Dewa Api atau Dewa Agni. Fungsi Dewa Agni yang berstana di Pura Hyang Api diyakini sebagai penguasa harta dan kekayaan bagi umat manusia. Selian itu sebagai istadewata tempat memohon kewarasan atau kesembuhan hewan ternak. Sebagai ucapan syukur umat yang memohon kesembuhan hewan ternaknya maka dilaksanakan Aci Keburan yang dimulai pada hari Raya Kuningan selama 35 hari. Hal inilah yang menjadikan keunikan yang tidak ada di pura lain di Bali.

Makna dari keberadaan Pura Hyang Api di Desa Kelusa tidak hanya bermanfaat bagi umat disekitar pura tetapi jug bagi seluruh umat Hindu diberbagai daerah di Bali dan luar Bali. Hal ini dapat dilihat pada saat upacara Aci Keburan umat yang dapat sampai membludak dari 8 kabupaten yang ada 
di Bali. Mereka ingin mengucap syukur atas kesembuhan hewan ternak serta membayar nazar atas terkabulnya permohonan yang mereka sampaikan ketika berdoa di pura ini. Berkah yang diberikan Tuhan yang Maha Esa atau Ida Sang Hyang Widhi wasa kepada umat pemujanya di pura meliputi kesejahteraan, kemakmuran, kebahagiaan kehidupan manusia dan segenap isi ekosistemnya.

\section{Daftar Pustaka}

Arwati, Ni Made Sri. 1998. Hari Raya Tumpek. Denpasar: Upada Sastra.

Budaarsa, Komang dkk, 2012. Profil Pura Kahyangan Jagat di Bali. Denpasar,LPPM Unud \& Udayana Press.

Kaler, I Gusti Ketut. 1983. Butir-Butir Tercecer Tentang Adat Bali. Denpasar: Bali Agung.

Koentjaraningrat. 1977. Metode-Metode Penelitian Masyarakat. Jakarta :Gramedia.

Kuntowijoyo. 2005. Metodologi Sejarah Edisi Kedua. Yogyakarta: PT. Tiara Wacana. Wiana, I Ketut. 2004. Tri Hita Karana Menurut Konsep Hindu. Surabaya: Paramita. Supartha, Ngurah Oka, 1996. Pura Hyang Api: Parahyangan Dewa Agni. Gianyar: Panitia Pembangunan Pura Hyang Api .

\section{Daftar Informan}

\begin{tabular}{clcl} 
No & Nama & Umur & Pekerjaan \\
\hline 1 & I Nyoman Suarka & 60 & Bendesa Pakraman Kelusa \\
2 & I Gusti Ngurah Jelantik & 60 & Mangku Pura Hyang Api \\
3 & I Made Parwata & 55 & Umat Pura Hyang Api
\end{tabular}

